\title{
Determination of residual solvents in paclitaxel by headspace gas chromatography
}

\author{
Khaleel Noorbasha ${ }^{1 *}$ (iD and Abdul Rahaman Shaik ${ }^{2}$
}

\begin{abstract}
Background: A simple and sensitive gas chromatographic method was developed and validated for the simultaneous determination of methanol, ethanol, acetone, isopropyl alcohol, dichloromethane, N-hexane, ethyl acetate, tetrahydrofuran, and $\mathrm{N}, \mathrm{N}$-diisopropyl ethyl amine in Paclitaxel. A chromatographic separation was done on DB-624 column, $30 \mathrm{~m}$ length $\times 0.53 \mathrm{~mm} \mathrm{ID}$, and film thickness $3 \mu \mathrm{m}$, using a flame ionization detector (FID) with gradient column oven temperature program. The injection was carried out in split mode, with a split ratio of 5:1. A mixture of $\mathrm{N}$-methyl-2-pyrrolidinone (contains 1\% piperazine) and water in the ratio of 80:20 (v/v) was selected as a diluent to obtain good sensitivity along with the recovery.

Results: The developed gas chromatographic method offers symmetric peak shape, good resolution of more than 2.0 between the solvent peaks, and the relative standard deviation for replicate injections of all the solvents were found to be not more than $15.0 \%$ with reasonable retention time for all the solvents. The limit of detection for methanol, ethanol, acetone, isopropyl alcohol, dichloromethane, $\mathrm{N}$-hexane, ethyl acetate, tetrahydrofuran, and N,N-diisopropyl ethyl amine was found to be $304.69 \mathrm{ppm}, 497.98 \mathrm{ppm}, 498.99 \mathrm{ppm}$, 504.49 ppm, 61.81 ppm, 30.07 ppm, 505 ppm, 73.05 ppm, and 2.09 ppm, respectively. Limit of quantitation of methanol, ethanol, acetone, isopropyl alcohol, dichloromethane, $N$-hexane, ethyl acetate, tetrahydrofuran, and $\mathrm{N}, \mathrm{N}$-diisopropyl ethyl amine was found to be $89.62 \mathrm{ppm}, 146.47 \mathrm{ppm}, 146.76 \mathrm{ppm}, 148.38 \mathrm{ppm}, 18.18 \mathrm{ppm}, 8.84$ ppm, 148.53 ppm, $21.49 \mathrm{ppm}$, and $0.62 \mathrm{ppm}$, respectively. Precision was found to be satisfactory. Linear in the range of LOQ to $150 \%$ level for all the solvents, and accuracy along with robustness, is performed, and acceptable results were obtained.
\end{abstract}

Conclusion: The proposed method was demonstrated to be simple, sensitive, specific, linear, precise, accurate, and robust, hence can be used to determine the residual organic solvents in Paclitaxel drug substance and drug product.

Keywords: Paclitaxel, Gas chromatography, Flame ionization detector

\footnotetext{
* Correspondence: khaleelnoorbasha@gmail.com

${ }^{1}$ Department of Pharmaceutical Sciences, Acharya Nagarjuna University,

Nagarjunanagar, Guntur, Andhra Pradesh 522510, India

Full list of author information is available at the end of the article
}

\section{Springer Open}

(c) The Author(s). 2021 Open Access This article is licensed under a Creative Commons Attribution 4.0 International License, which permits use, sharing, adaptation, distribution and reproduction in any medium or format, as long as you give appropriate credit to the original author(s) and the source, provide a link to the Creative Commons licence, and indicate if changes were made. The images or other third party material in this article are included in the article's Creative Commons licence, unless indicated otherwise in a credit line to the material. If material is not included in the article's Creative Commons licence and your intended use is not permitted by statutory regulation or exceeds the permitted use, you will need to obtain permission directly from the copyright holder. To view a copy of this licence, visit http://creativecommons.org/licenses/by/4.0/. 


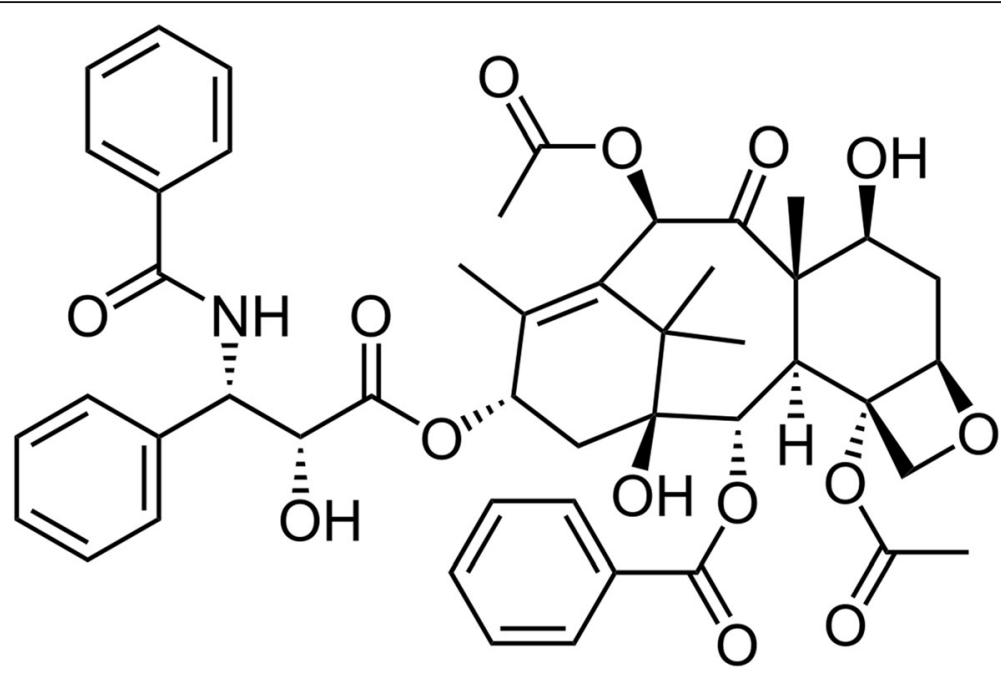

Fig. 1 Chemical Structure of Paclitaxel. Molecular Formula: $\mathrm{C}_{47} \mathrm{H}_{51} \mathrm{NO}_{14}$. Molecular weight: $853.9 \mathrm{~g} / \mathrm{mol}$

\section{Background}

Paclitaxel [1] (Fig. 1) is a taxane derivative originally derived in limited amounts from the bark of the pacific yew tree Taxus brevifolia (Taxaceae). It is now obtained from a taxane precursor derived from the needles of the European yew, Taxus bacata, using a semi-synthetic process. It is a BCS class IV drug with a high degree of hydrophobicity and consequently an extremely low aqueous solubility of $4 \mu \mathrm{g} / \mathrm{mL}[2,3]$. Paclitaxel has shown significant activity against a wide range of tumors such as those in breast, ovarian, and lung cancer, in addition to head and neck carcinomas [4]. An impurity in a drug substance was defined by the International Conference on Harmonisation (ICH) guidelines that are any component of the drug substance that is not the chemical entity defined as the drug substance and affects the purity of active ingredient or drug substances [5]. Similarly, an impurity in a drug product is any component of the drug product that is not the chemical entity defined as the drug substance or an excipient in the drug product [6]. Therefore, any extraneous material present

Table 1 Residual solvent with their class and limits

\begin{tabular}{lll}
\hline Solvent & Class & Limit (ppm) \\
\hline Acetone & 3 & 5000 \\
Isopropyl alcohol & 3 & 5000 \\
Methanol & 2 & 3000 \\
Ethanol & 3 & 5000 \\
Dichloromethane & 2 & 600 \\
n-Hexane & 2 & 290 \\
Ethylacetate & 3 & 5000 \\
Tetrahydrofuran & 2 & 720 \\
N,N-diisopropyl ethylamine & 1 & 20 \\
\hline
\end{tabular}

in the drug substance has to be considered an impurity even if it is inert or has superior pharmacological properties. The impurity profile of pharmaceuticals is of increasing importance as drug safety receives more and more attention from the public and the media. Several recent books and journal reviews address this topic, and guidelines are available from the USA and international authorities [7-14]. Most active pharmaceutical ingredients (APIs) are produced by organic chemical synthesis. Various components including residual solvents trace amounts of inorganic, and organic components, can be generated during such processes.

Analysis of a residual solvent in pharmaceuticals is an important issue due to the potential risk to human health from the toxicity of many of these solvents. The

Table 2 Optimized gas chromatographic conditions

\begin{tabular}{ll}
\hline Parameter & Condition \\
\hline Carrier gas & Helium \\
Flow rate & $2.5 \mathrm{~mL} / \mathrm{min}$ \\
Injector temperature & $180^{\circ} \mathrm{C}$ \\
Carrier gas mode & Split \\
Split ratio & $5: 1$ \\
Split flow & $20 \mathrm{~mL} / \mathrm{min}$ \\
Detector & $\mathrm{FID}$ \\
Detector temperature & $260^{\circ} \mathrm{C}$ \\
Hydrogen flow & $40 \mathrm{~mL} / \mathrm{min}$ \\
Air flow & $400 \mathrm{~mL} / \mathrm{min}$ \\
Make-up gas flow (helium) & $25 \mathrm{~mL} / \mathrm{min}$ \\
Run time & $30 \mathrm{~min}$ \\
Oven temperature & $\mathrm{T}_{1} 40^{\circ} \mathrm{C} ;$ hold for $12 \mathrm{~min}$ \\
& $\mathrm{~T}_{2} 220^{\circ} \mathrm{C}$ at the rate of $25^{\circ} \mathrm{C} / \mathrm{min} ;$ \\
\hline
\end{tabular}


Table 3 Optimized headspace conditions

\begin{tabular}{ll}
\hline System parameter & Optimum conditions \\
\hline Oven temperature & $90^{\circ} \mathrm{C}$ \\
Loop temperature & $100^{\circ} \mathrm{C}$ \\
Transfer line temperature & $110^{\circ} \mathrm{C}$ \\
GC cycle time & $40 \mathrm{~min}$ \\
Vial equilibration time & $30 \mathrm{~min}$ \\
Vial pressurization time & $0.5 \mathrm{~min}$ \\
Loop fill time & $0.5 \mathrm{~min}$ \\
Loop equilibration time & $0.05 \mathrm{~min}$ \\
Injection time & $1.0 \mathrm{~min}$ \\
Vial agitation & Low \\
\hline
\end{tabular}

amount of such solvents is, therefore, limited by $\mathrm{ICH}$ guidelines [15]. The ICH has published the limits of the residual solvents that considered safe in pharmaceutical preparations; also, it has published the daily exposure limits for these solvents. It has classified these solvents in three categories depending on their toxicity. Class I solvents are known human carcinogens and environmental hazards, and the use of these solvents should be avoided if at all possible. Class II solvents are nongenotoxic animal carcinogens or possible causative agents of other irreversible toxicities such as neurotoxicity or teratogenicity. The use of these solvents should be limited. Class III solvents are the solvents with the low toxic potential to man, and no health-based exposure limit is needed. The list of solvents with their class and limits is given in Table 1. In the pharmaceutical industries, all the pharmaceutical products must be analyzed for residual solvent content, regardless of the matrix.

Gas chromatography is generally used to determine residual solvents due to its excellent separation ability and high sensitivity. In gas chromatography, the sample is either dissolved in a suitable solvent than injected directly [16] or by headspace sampling. Headspace sampling is preferred due to its ability to avoid direct liquid or solid probing. In the headspace sampling, complex sample matrix in a solid or liquid sample matrix in the liquid or solid sample can be simplified or even eliminated in its vapor phase [17]. Different methods have been reported in the literature for the determination of Paclitaxel, e.g., capillary electrophoresis [18], LC-MS [19], and high performance liquid chromatography (HPLC) [20, 21]. Also, there are many reports that use HPLC technique to determine related substances in plant extracts, raw material, and taxol preparations [22-29].

The objective of this work is to develop and validate a new gas chromatographic method for the simultaneous determination of residual solvents in Paclitaxel. These solvents should be estimated and checked so that they may not exceed the amount specified by the $\mathrm{ICH}$ guidelines.

\section{Methods \\ Materials}

Paclitaxel raw material was procured from the Spectrum Pharma Research Private Limited, Hyderabad, India. GC grade methanol, ethanol, acetone, isopropyl alcohol, dichloromethane, n-hexane, ethylacetate, tetrahydrofuran, $N, N$-diisopropyl ethylamine, $N$-methyl 1-2-pyrrolidinone, and piperazine were purchased from the Merck India Limited, Mumbai, India.

\section{Instrumentation}

A gas chromatograph (Agilent Technologies 6890A) equipped with flame ionization detector (FID) connected to Agilent G1888 Headspace sampler and a data processor Waters Empower 3 software was employed. The column utilized was DB-624, $30 \mathrm{~m}$ length $\times 0.53 \mathrm{~mm}$ ID, and film thickness $3 \mu \mathrm{m}$. Meltronics sonicator was used to enhance the solubility of the material. Sartorius balance was employed for weighing the samples.

\section{Optimized chromatographic conditions}

Various GC columns such as DB- 1 and DB-5 were used of various dimensions, but the best separation was achieved on DB-624, $30 \mathrm{~m}$ length $\times 0.53 \mathrm{~mm} \mathrm{ID}$, and

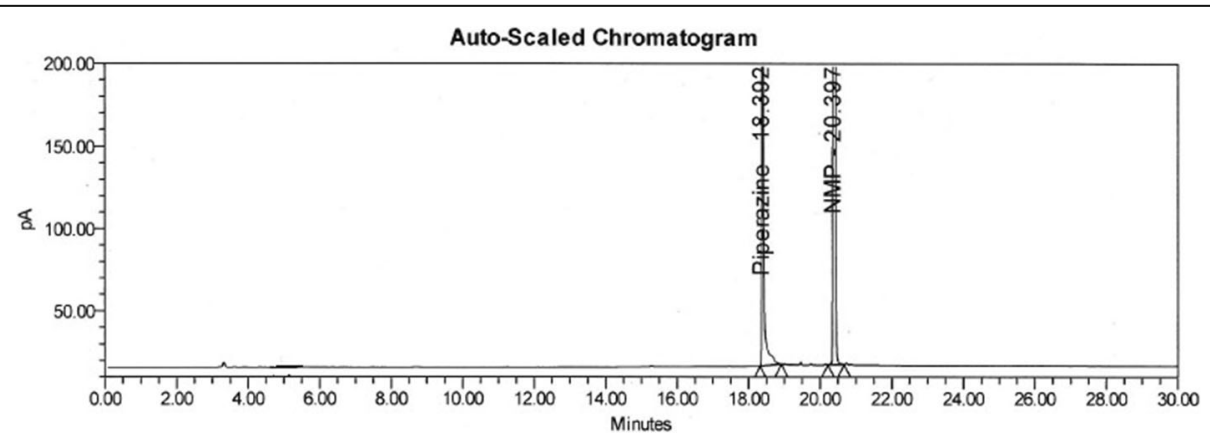

Fig. 2 Typical Chromatogram of Blank 


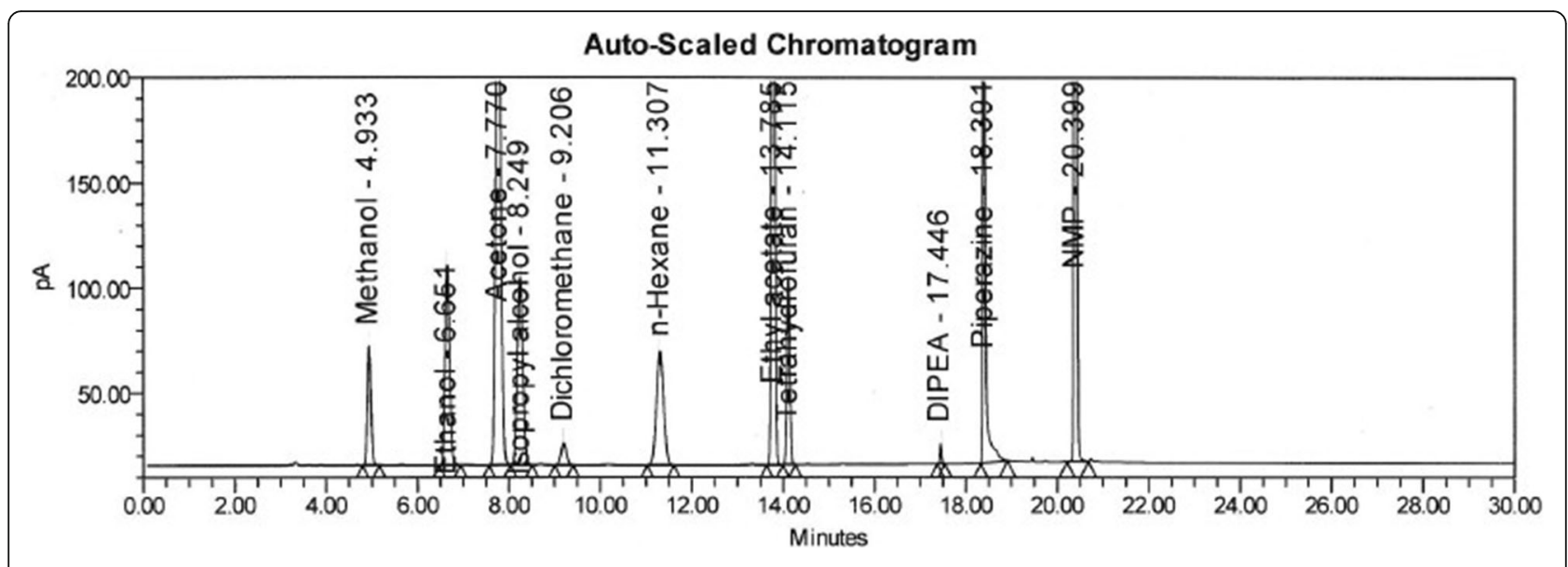

Fig. 3 Typical Chromatogram of Standard

film thickness $3 \mu \mathrm{m}$. Details of other optimized gas chromatographic and headspace parameters are given in Tables 2 and 3, respectively.

Preparation of diluent (mixture of $\mathrm{N}$-methyl-2pyrrolidinone (contains $1 \%$ piperazine and water in the ratio of $80: 20 \mathrm{v} / \mathrm{v}$ )

Accurately weigh and transfer about $1.0 \mathrm{~g}$ of piperazine in $100 \mathrm{~mL}$ volumetric flask (1\%). Add about $25 \mathrm{~mL}$ of $\mathrm{N}$ methyl-2-pyrrolidinone (NMP) solvent to this volumetric flask. Sonicate the flask till the piperazine completely dissolves in $N$-methyl-2-pyrrolidinone (NMP). Transfer $20 \mathrm{~mL}$ of water into this solution (20\%). Mix this solution thoroughly and adjust to volume with the same solvent $N$-methyl-2-pyrrolidinone.

\section{Blank solution}

Transfer $1 \mathrm{~mL}$ of diluent into Agilent Technologies manufactured $20 \mathrm{~mL}$ flat bottom headspace GC vials fitted with a septum and crimp cap and seal. The chromatogram of blank solution showed in Fig. 2.
Preparation of $\mathrm{N}, \mathrm{N}$-diisopropyl ethyl amine stock solution (DIPEA)

Accurately weigh and transfer about $20 \mathrm{mg}$ of DIPEA in $10 \mathrm{~mL}$ volumetric flask containing about $5 \mathrm{~mL}$ of diluent and mix and adjust to volume with diluent.

\section{Preparation of DIPEA standard solution}

Transfer $1 \mathrm{~mL}$ of above DIPEA standard stock solution into $20 \mathrm{~mL}$ volumetric flask containing $5 \mathrm{~mL}$ of diluent and mix and adjust to volume with diluent.

\section{Preparation of standard stock solution-A}

Accurately weigh and transfer about $150 \mathrm{mg}$ of methanol, $250 \mathrm{mg}$ of ethanol, $250 \mathrm{mg}$ of acetone, $250 \mathrm{mg}$ of isopropyl alcohol, $250 \mathrm{mg}$ of ethyl acetate, $36 \mathrm{mg}$ of tetrahydrofuran, $30 \mathrm{mg}$ of dichloromethane, and $15 \mathrm{mg}$ of $\mathrm{n}$-hexane in $10 \mathrm{~mL}$ volumetric flask containing about $1 \mathrm{~mL}$ of diluent mix and made up to the mark with diluent.

Table 4 Results of system suitability study

\begin{tabular}{|c|c|c|c|c|c|}
\hline Solvent name & Retention time & $\begin{array}{l}\text { Percentage RSD for area count } \\
\text { of six replicate injection of standard }\end{array}$ & Tailing factor & Theoretical plates & Resolution \\
\hline Methanol & 4.93 & 2.5 & 1.0 & 58451 & NA \\
\hline Ethanol & 6.65 & 1.6 & 1.1 & 78485 & 10.3 \\
\hline Acetone & 7.77 & 1.4 & 1.2 & 95214 & 5.8 \\
\hline Isopropyl alcohol & 8.25 & 2.0 & 1.0 & 32548 & 2.2 \\
\hline Dichloromethane & 9.21 & 3.2 & 1.4 & 12547 & 4.2 \\
\hline N-Hexane & 11.31 & 3.4 & 1.3 & 78987 & 8.0 \\
\hline Ethyl acetate & 13.79 & 1.7 & 1.1 & 65848 & 12.0 \\
\hline Tetrahydrofuran & 14.12 & 2.8 & 1.0 & 97845 & 2.9 \\
\hline DIPEA & 17.45 & 3.5 & 1.2 & 98751 & 32.1 \\
\hline Acceptance Criteria & For information & NMT 15.0 & NMT 2.0 & NLT 2000 & NLT 1.5 \\
\hline
\end{tabular}


Table $\mathbf{5}$ Linearity and range of solvents

\begin{tabular}{|c|c|c|c|c|c|c|c|}
\hline \multirow{2}{*}{$\begin{array}{l}\text { S. } \\
\text { no. }\end{array}$} & \multirow{2}{*}{$\begin{array}{l}\text { Percentage } \\
\text { level }\end{array}$} & \multicolumn{2}{|l|}{ Methanol } & \multicolumn{2}{|l|}{ Ethanol } & \multicolumn{2}{|l|}{ Acetone } \\
\hline & & Concentration (ppm) & Mean peak area & Concentration (ppm) & Mean peak area & Concentration (ppm) & Mean peak area \\
\hline 1 & LOQ & 304.59 & 31.74 & 496.78 & 65.82 & 499.256 & 191.247 \\
\hline 2 & 50 & 1524.63 & 159.71 & 2571.21 & 330.18 & 2495.98 & 962.2365 \\
\hline 3 & 75 & 2287.51 & 237.16 & 3735.28 & 491.58 & 3748.47 & 1445.855 \\
\hline 4 & 100 & 3047.95 & 318.42 & 4981.75 & 659.25 & 4990.96 & 1928.473 \\
\hline 5 & 125 & 3809.8 & 396.85 & 6225.8 & 823.71 & 6247.45 & 2404.091 \\
\hline 6 & 150 & 4571.42 & 475.28 & 7470.56 & 989.23 & 7480.94 & 2885.71 \\
\hline
\end{tabular}

\section{Preparation of standard solution}

Transfer $0.8 \mathrm{~mL}$ of DIPEA standard solution and $0.8 \mathrm{~mL}$ of standard stock solution-A into $50 \mathrm{~mL}$ volumetric flask containing about $20 \mathrm{~mL}$ of diluent and mix until the volume was made up to the mark with diluent.

Transfer $1 \mathrm{~mL}$ of this solution into $20 \mathrm{~mL}$ headspace GC vial and seal vial adequately fitted with a septum and crimp cap.

This standard solution contains about $3000 \mathrm{ppm}$ of methanol, $5000 \mathrm{ppm}$ of ethanol, $5000 \mathrm{ppm}$ of acetone, $5000 \mathrm{ppm}$ of isopropylalcohol, $5000 \mathrm{ppm}$ of ethylacetate, $720 \mathrm{ppm}$ of tetrahydrofuran, $600 \mathrm{ppm}$ of dichloromethane, $290 \mathrm{ppm}$ of $\mathrm{n}$-hexane, and $20 \mathrm{ppm}$ of DIPEA (with respect to test concentration). The chromatogram of standard solution showed in Fig. 3.

\section{Sample preparation}

Weigh accurately about $80 \mathrm{mg}$ of sample for evaluation into $20 \mathrm{~mL}$ flat bottom headspace GC vials and add 1 $\mathrm{mL}$ of diluent fitted with a septum and crimp cap and seal.

\section{Results}

\section{Method validation}

The developed method was validated according to the $\mathrm{ICH}$ guidelines with reference to accuracy, precision, system suitability, specificity, linearity, limit of quantification, limit of detection, and robustness [30].

\section{System suitability}

System performance parameters of the optimized GC method were determined by analyzing standard solution. Chromatographic parameters such as number of theoretical plates, tailing factor, and resolution were determined. The results are within the specifications, indicating the excellent performance of the system. System repeatability was established by six replicate injections of the standard solution, and the relative standard deviations (RSD) for the peak area of the solvents were calculated to evaluate the repeatability. The obtained results were within the $\mathrm{ICH}$ permissible limits mentioned in Table 4. The blank chromatogram is shown in Fig. 2, and the typical chromatogram shows that all the solvents are shown in Fig. 3.

\section{Linearity}

The linearity of the relationship between the peak area and the concentration in ppm evaluated for all the residual solvents mentioned in the present study was investigated by linear regression analysis. Six linearity solutions were prepared to range from limit of quantitation LOQ to $150 \%$ of the specified level concentration of each solvent. The linear range investigated for each solvent is mentioned in Tables 5, 6 and 7. Linearity curves were drawn by plotting the graph of the average peak area of solvent against its concentration in ppm for linearity solutions, Figs. 4, $5,6,7,8,9,10,11$, and 12 .

Table 6 Linearity and range of solvents

\begin{tabular}{|c|c|c|c|c|c|c|c|}
\hline \multirow{2}{*}{$\begin{array}{l}\text { S. } \\
\text { no. }\end{array}$} & \multirow{2}{*}{$\begin{array}{l}\text { Percentage } \\
\text { level }\end{array}$} & \multicolumn{2}{|l|}{ Isopropyl alcohol } & \multicolumn{2}{|l|}{ Dichloromethane } & \multicolumn{2}{|l|}{ n-hexane } \\
\hline & & Concentration (ppm) & Mean peak area & Concentration (ppm) & Mean peak area & Concentration (ppm) & Mean peak area \\
\hline 1 & LOQ & 503.495 & 74.924 & 60.814 & 8.9874 & 29.7699 & 57.778 \\
\hline 2 & 50 & 2524.475 & 381.62 & 310.07 & 45.937 & 153.3495 & 294.89 \\
\hline 3 & 75 & 3785.713 & 570.43 & 465.605 & 68.4055 & 227.5243 & 443.835 \\
\hline 4 & 100 & 5046.95 & 760.24 & 620.14 & 90.874 & 304.699 & 584.78 \\
\hline 5 & 125 & 6304.188 & 950.05 & 775.675 & 113.3425 & 377.8738 & 736.725 \\
\hline 6 & 150 & 7569.425 & 1140.86 & 929.21 & 136.811 & 456.0485 & 883.67 \\
\hline
\end{tabular}


Table 7 Linearity and range of solvents

\begin{tabular}{|c|c|c|c|c|c|c|c|}
\hline \multirow{2}{*}{$\begin{array}{l}\text { S. } \\
\text { no. }\end{array}$} & \multirow{2}{*}{$\begin{array}{l}\text { Percentage } \\
\text { level }\end{array}$} & \multicolumn{2}{|l|}{ Ethylacetate } & \multicolumn{2}{|l|}{ Tetrahydrofuran } & \multicolumn{2}{|l|}{ DIPEA } \\
\hline & & Concentration (ppm) & Mean peak area & Concentration (ppm) & Mean peak area & Concentration (ppm) & Mean peak area \\
\hline 1 & LOQ & 501.24 & 178.8986 & 71.0536 & 38.6221 & 2.0984 & 3.018 \\
\hline 2 & 50 & 2526.45 & 897.493 & 367.268 & 199.1105 & 10.4985 & 15.0979 \\
\hline 3 & 75 & 3788.5 & 1350.24 & 546.902 & 298.1658 & 15.6401 & 22.648 \\
\hline 4 & 100 & 5047.5 & 1799.986 & 731.536 & 397.221 & 20.98685 & 30.181 \\
\hline 5 & 125 & 6311.5 & 2244.733 & 914.17 & 496.2763 & 26.2482 & 37.723 \\
\hline 6 & 150 & 7574.58 & 2697.479 & 1096.804 & 595.3315 & 31.4706 & 45.269 \\
\hline
\end{tabular}

\section{Accuracy and precision}

Both the terms accuracy and precision are mutually correlated, where accuracy is the difference between the true value and the observed value. With the precision, it has a limited significance. Accuracy and precision were determined by applying the optimized method in which known amount of each solvent corresponding to LOQ, $50 \%, 100 \%$, and $150 \%$ of specified target concentration. Each level was prepared in triplicate. The accuracy was then calculated as the percentage of analyte recovered. From the results, it is evident that the recovery of each in spiked samples ranged from 97.0 to $115.0 \%$. Mean recoveries for all the solvents are shown in Tables 8, 9, 10, $11,12,13,14,15$ and 16.

The precision of an analytical procedure expresses the closeness of agreement (degree of scattering) between a series of measurements obtained from multiple sampling of the same homogeneous sample under the prescribed conditions. Precision may be considered at three levels: repeatability, intermediate precision, and reproducibility. The precision of an analytical procedure is usually expressed as the variance, standard deviation, or coefficient of variation of a series of measurements. Method precision shall be established by determining the assay in six different preparations of a standard solution. Intermediate precision shall be determined by studying the variation in assay of a homogeneous sample analyzed by two different equipment, analyst and days. The average, standard deviation, and relative standard deviation shall be calculated. The results for the method and intermediate precision are found to be under the acceptable limit for each residual solvent as revealed by relative standard deviation data (RSD < $15.0 \%$ for the solvents). The precision results are shown in Table 17.

\section{Limit of detection (LOD) and limit of quantitation (LOQ)}

The limit of detection of an individual analytical procedure is the lowest amount of analyte in a sample, which can be detected but not necessarily quantitated as an exact amount. While the limit of quantitation was the minimum level of concentration of analyte at which it can be quantitated with acceptable precision and accuracy. LOD and LOQ were calculated using the signal-tonoise ratio $(\mathrm{S} / \mathrm{N})$ method using the Empower software. Six replicate solutions were injected into the chromatograph and recorded. Obtained LOD and LOQ of each solvent are mentioned in Table 18.

\section{Robustness}

For robustness, three deliberate changes were done concerning carrier gas flow rate, column oven temperature, and vial oven temperature. Each change consists of one upper set and one lower set. For each set, six replicate determinations were analyzed. The results were found to

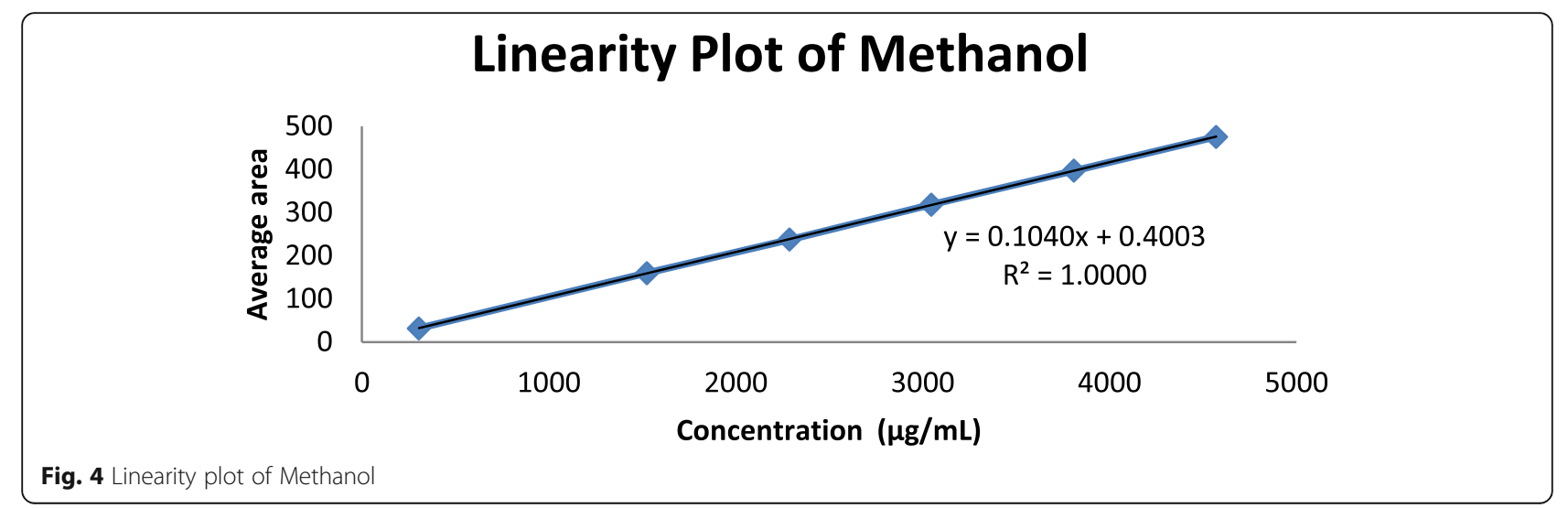




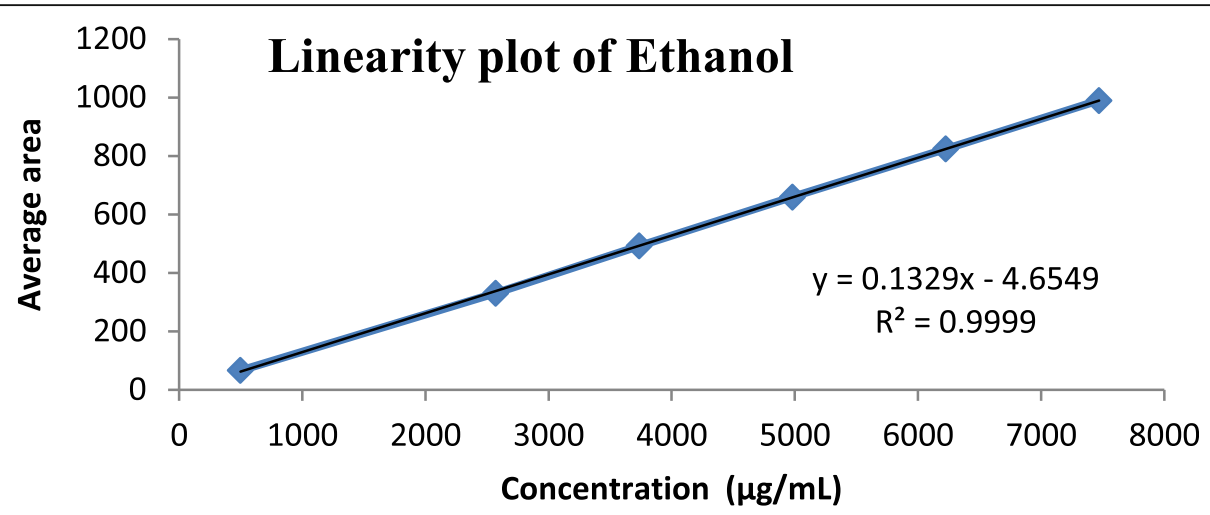

Fig. 5 Linearity plot of Ethanol

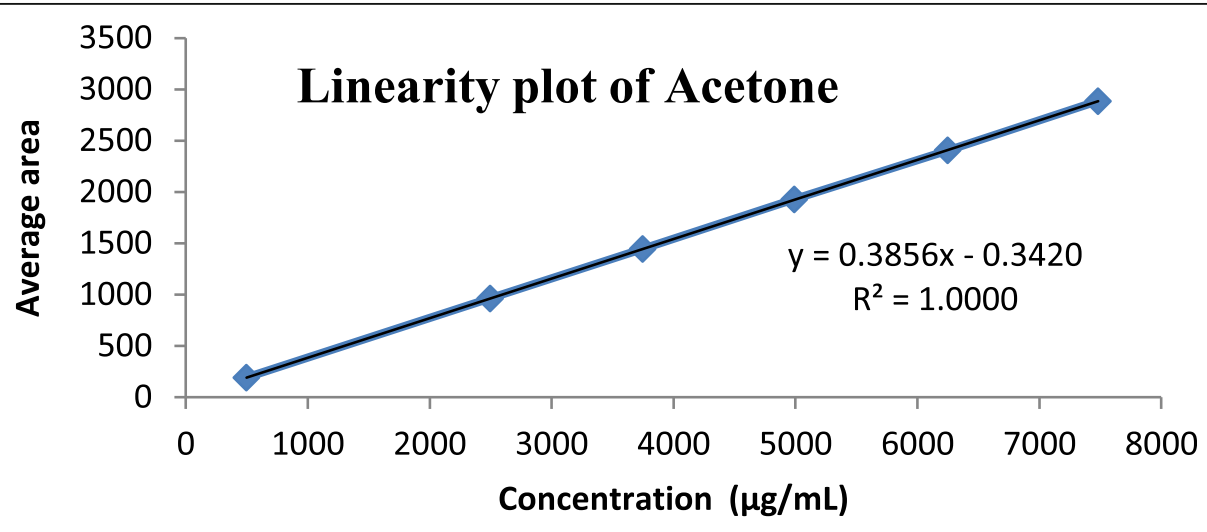

Fig. 6 Linearity plot of Acetone

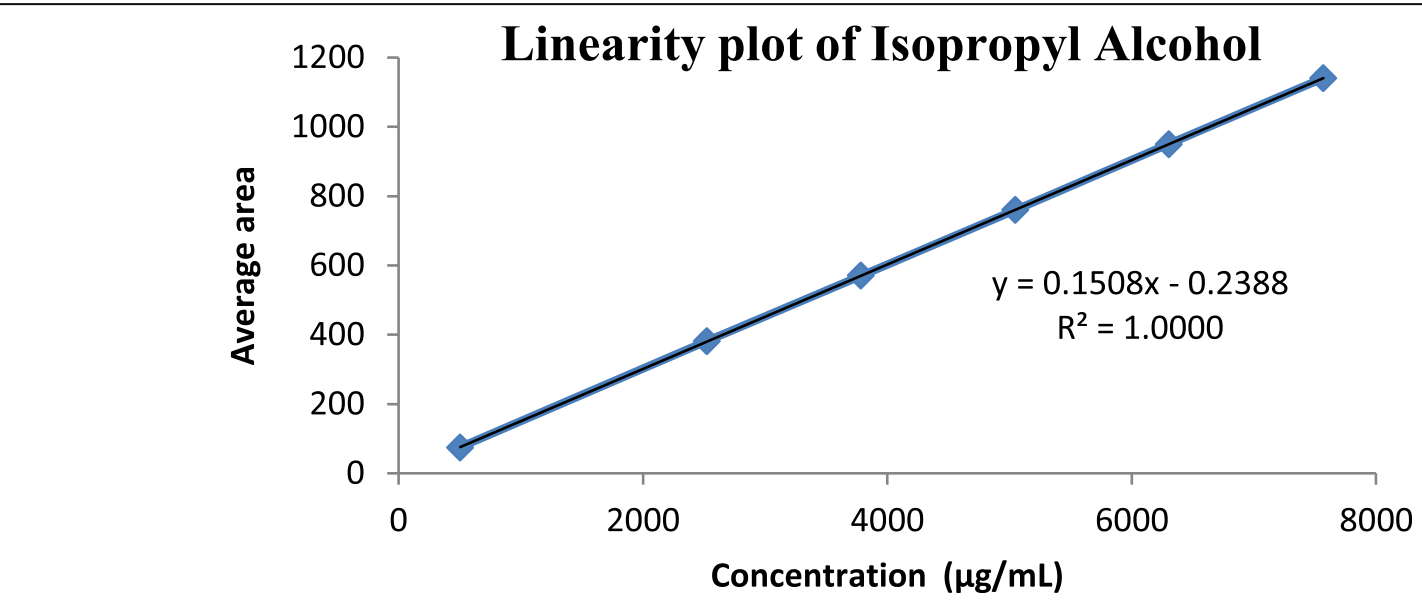

Fig. 7 Linearity plot of Isopropyl Alcohol 


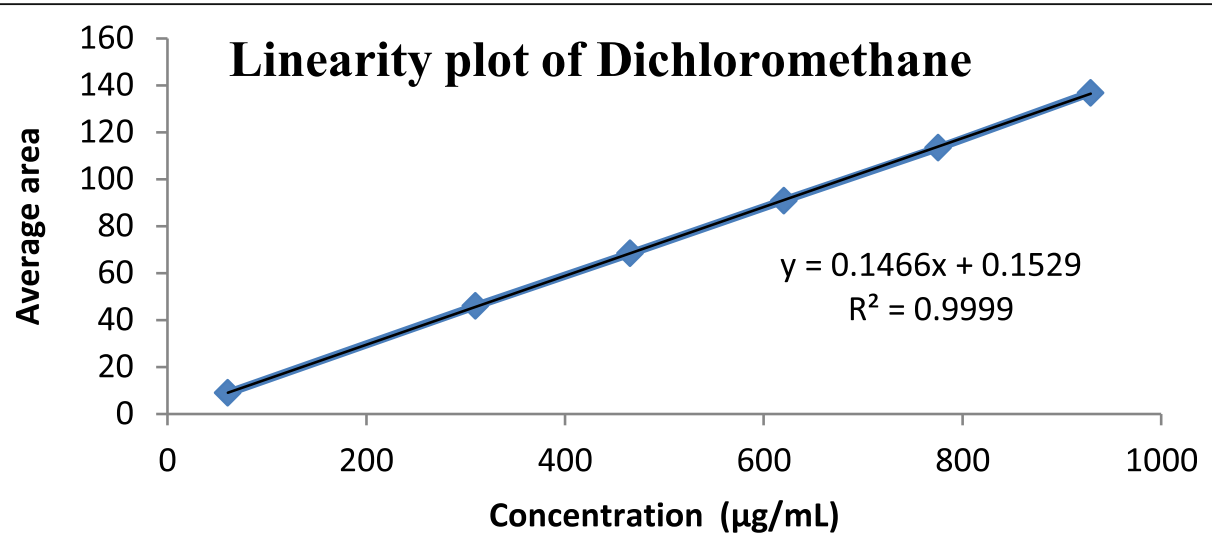

Fig. 8 Linearity plot of Dichloromethane

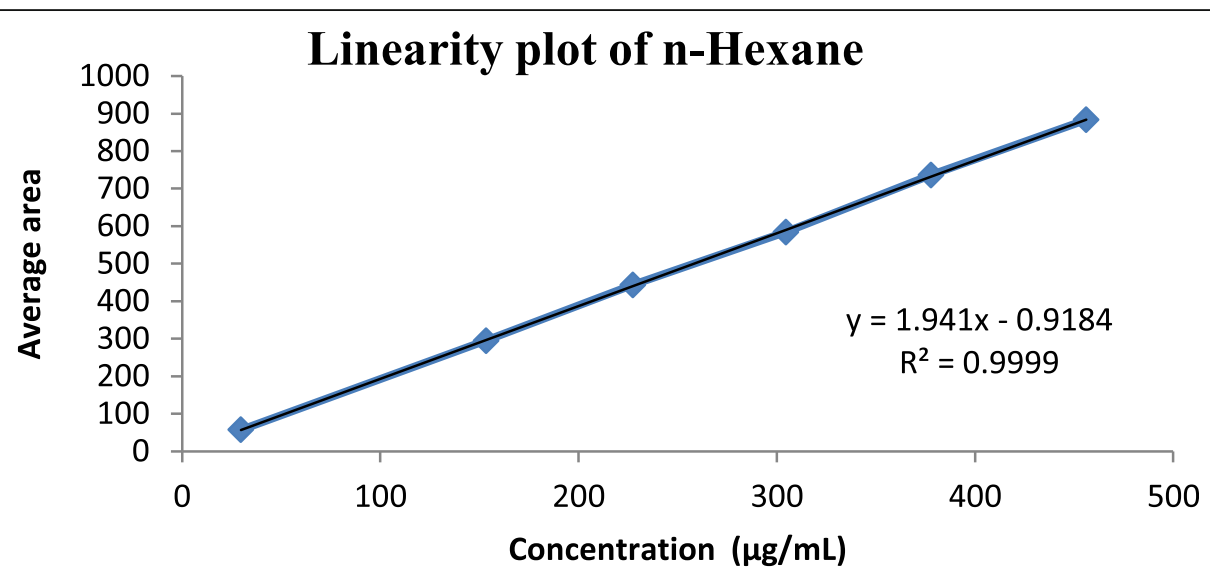

Fig. 9 Linearity plot of n-Hexane

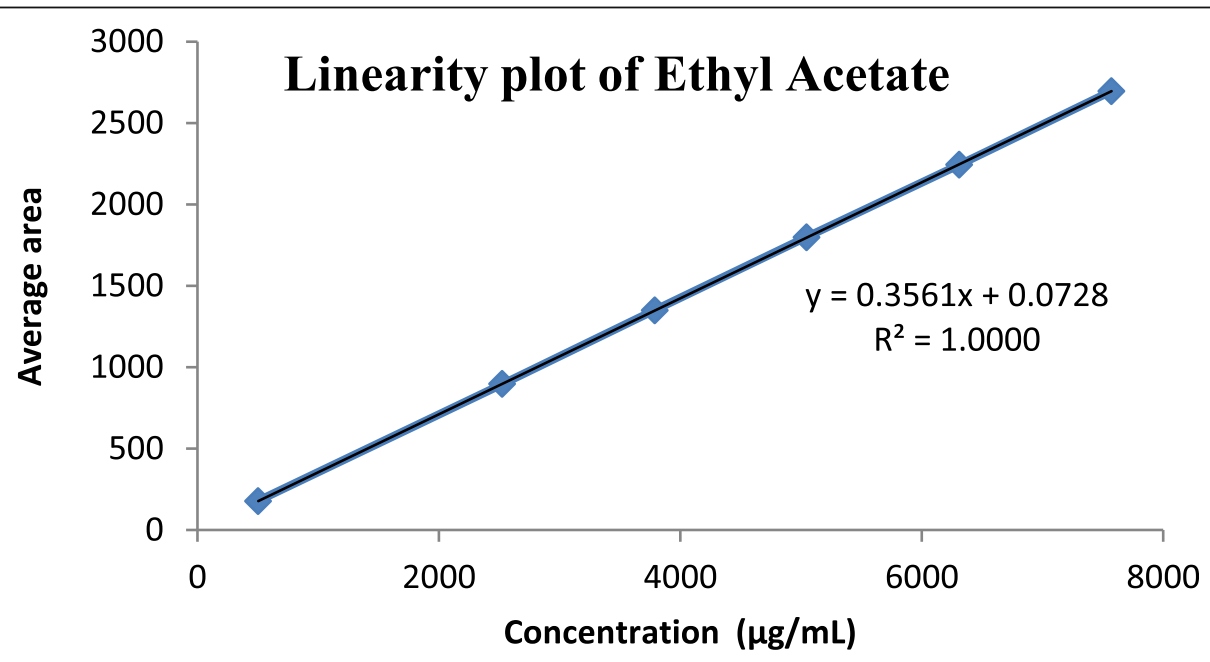

Fig. 10 Linearity plot of Ethylacetate 


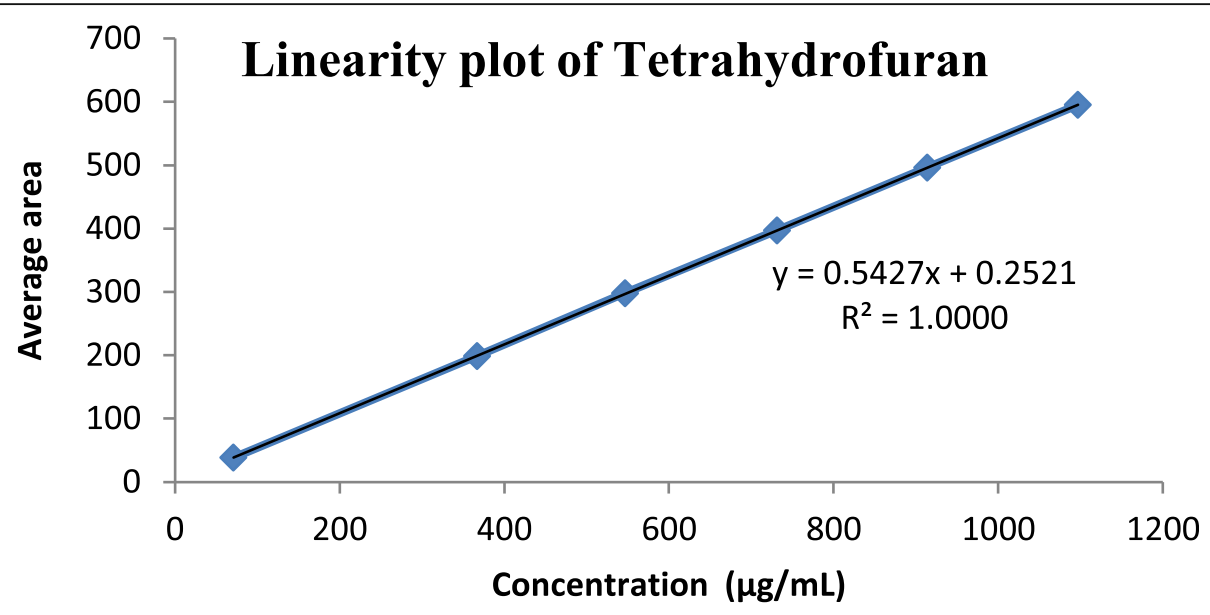

Fig. 11 Linearity plot of Tetrahydrofuran

be satisfactory and within the acceptable limits. The obtained results are mentioned in Tables 19, 20, 21, 22, 23, $24,25,26$, and 27.

\section{Discussion}

In this research study involved a new gas chromatographic method for determination of residual solvents in bulk. Different methods have shown by using different analytical techniques for the determination of Paclitaxel [18-29]. However, the gas chromatographic method for determination of residual solvents has not been reported earlier.

The primary goal of this study is to provide a simple and sensitive gas chromatographic method for the determination of all the residual solvents present in the active analyte. During the development of the analytical method, trails were done and optimized the method and found to be feasible and can be adoptable. The system suitability parameters like injection repeatability, number of theoretical plates, tailing factor, and resolution results were met the USP acceptance limits (Table 4), which resembles integrity of the system.

The retention time of the solvent peaks of standard solution matches with that of the spiked test sample solution. No interference was observed at a retention time of the solvent peak from blank and test sample Figs. 2 and 3 which clearly resembles the specificity of the proposed method. The percentage recovery obtained for each solvent was in the range of $80-120 \%$, which is within $\mathrm{ICH}$ acceptance. Precision parameter shows that the RSD was $<5.0 \%$ for all the solvents in system precision, repeatability, and intermediate precision at $100 \%$ concentration which proved that the developed analytical method was accurate and precise (Tables 8, 9, 10, 11, 12, 13, 14, 15, 16 and 17). Linearity was observed in the concentration range of LOQ to $150 \%$ with $r^{2}$ values $>0.999$ and $y$ -

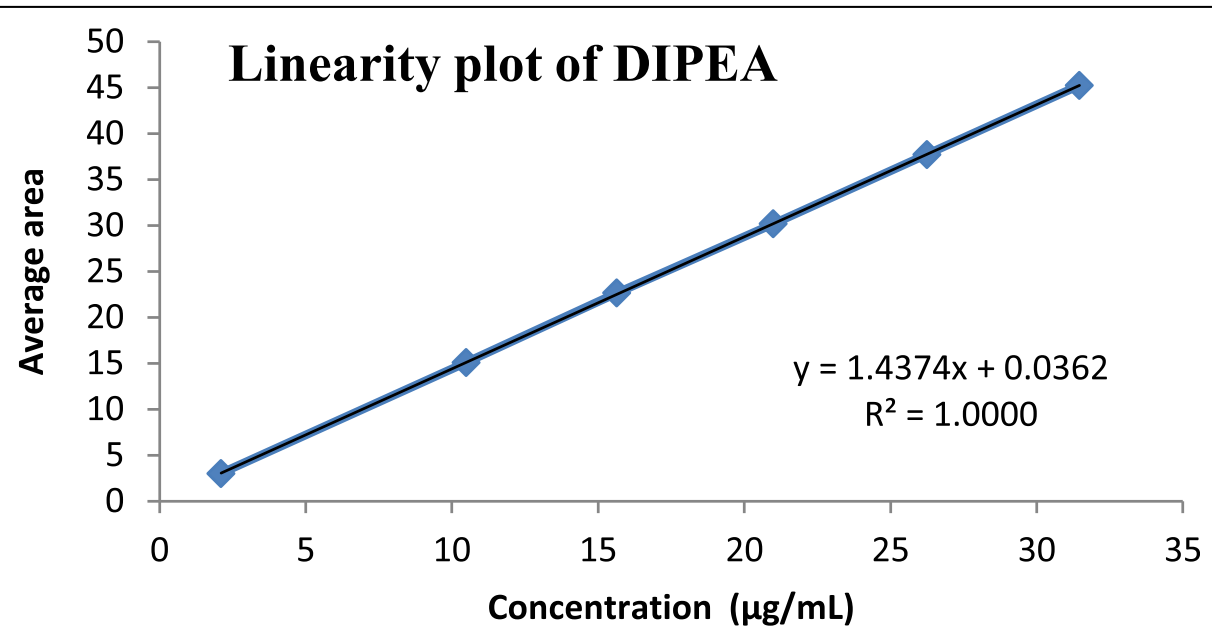

Fig. 12 Linearity plot of DIPEA 
Table 8 Results of recovery study for methanol

\begin{tabular}{|c|c|c|c|c|}
\hline S. no. & Recovery level (\%) & Amount added (ppm) & Amount recovered (ppm) & Recovery (\%) \\
\hline \multirow[t]{3}{*}{1} & LOQ & 304.69 & 305.48 & 100.26 \\
\hline & & & 317.21 & 104.11 \\
\hline & & & 304.75 & 100.02 \\
\hline \multirow[t]{3}{*}{2} & 50 & 1523.47 & 1522.51 & 99.94 \\
\hline & & & 1521.24 & 99.85 \\
\hline & & & 1522.48 & 99.94 \\
\hline \multirow[t]{3}{*}{3} & 100 & 3046.95 & 3047.58 & 100.02 \\
\hline & & & 3057.98 & 100.36 \\
\hline & & & 3146.48 & 103.27 \\
\hline \multirow[t]{3}{*}{4} & 150 & 4570.42 & 4571.42 & 100.02 \\
\hline & & & 4669.75 & 102.17 \\
\hline & & & 4771.25 & 104.39 \\
\hline
\end{tabular}

Table 9 Results of recovery study for ethanol

\begin{tabular}{|c|c|c|c|c|}
\hline S. no. & Recovery level (\%) & Amount added (ppm) & Amount recovered (ppm) & Recovery (\%) \\
\hline \multirow[t]{3}{*}{1} & LOQ & 497.984 & 505.25 & 101.46 \\
\hline & & & 488.58 & 98.11 \\
\hline & & & 489.74 & 98.34 \\
\hline \multirow[t]{3}{*}{2} & 50 & 2489.92 & 2497.87 & 100.32 \\
\hline & & & 2418.82 & 97.14 \\
\hline & & & 2487.85 & 99.92 \\
\hline \multirow[t]{3}{*}{3} & 100 & 4979.84 & 4999.74 & 100.40 \\
\hline & & & 4885.24 & 98.10 \\
\hline & & & 4878.89 & 97.97 \\
\hline \multirow[t]{3}{*}{4} & 150 & 7469.76 & 7570.65 & 101.35 \\
\hline & & & 7465.58 & 99.94 \\
\hline & & & 7379.58 & 98.79 \\
\hline
\end{tabular}

Table 10 Results of recovery study for acetone

\begin{tabular}{|c|c|c|c|c|}
\hline S. no. & Recovery level (\%) & Amount added (ppm) & Amount recovered (ppm) & Recovery (\%) \\
\hline \multirow[t]{3}{*}{1} & LOQ & 498.996 & 500.24 & 100.25 \\
\hline & & & 489.57 & 98.11 \\
\hline & & & 487.99 & 97.79 \\
\hline \multirow[t]{3}{*}{2} & 50 & 2494.98 & 2591.89 & 103.88 \\
\hline & & & 2625.87 & 105.25 \\
\hline & & & 2589.78 & 103.80 \\
\hline \multirow[t]{3}{*}{3} & 100 & 4989.96 & 4978.89 & 99.78 \\
\hline & & & 5010.78 & 100.42 \\
\hline & & & 5045.78 & 101.12 \\
\hline \multirow[t]{3}{*}{4} & 150 & 7484.94 & 7515.84 & 100.41 \\
\hline & & & 7457.87 & 99.64 \\
\hline & & & 7428.48 & 99.25 \\
\hline
\end{tabular}


Table 11 Results of recovery study for isopropyl alcohol

\begin{tabular}{|c|c|c|c|c|}
\hline S. no. & Recovery level (\%) & Amount added (ppm) & Amount recovered (ppm) & Recovery (\%) \\
\hline \multirow[t]{3}{*}{1} & LOQ & 504.495 & 499.25 & 98.96 \\
\hline & & & 497.58 & 98.63 \\
\hline & & & 501.41 & 99.39 \\
\hline \multirow[t]{3}{*}{2} & 50 & 2522.475 & 2491.27 & 98.76 \\
\hline & & & 2511.49 & 99.56 \\
\hline & & & 2485.87 & 98.55 \\
\hline \multirow[t]{3}{*}{3} & 100 & 5044.95 & 5030.85 & 99.72 \\
\hline & & & 5081.25 & 100.72 \\
\hline & & & 5019.48 & 99.50 \\
\hline \multirow[t]{3}{*}{4} & 150 & 7567.425 & 7518.25 & 99.35 \\
\hline & & & 7458.74 & 98.56 \\
\hline & & & 7489.85 & 98.97 \\
\hline
\end{tabular}

Table 12 Results of recovery study for dichloromethane

\begin{tabular}{|c|c|c|c|c|}
\hline S. no. & Recovery level (\%) & Amount added (ppm) & Amount recovered (ppm) & Recovery (\%) \\
\hline \multirow[t]{3}{*}{1} & LOQ & 61.81 & 60.79 & 98.35 \\
\hline & & & 59.78 & 96.72 \\
\hline & & & 59.74 & 96.65 \\
\hline \multirow[t]{3}{*}{2} & 50 & 309.07 & 305.48 & 98.84 \\
\hline & & & 305.48 & 98.84 \\
\hline & & & 300.78 & 97.32 \\
\hline \multirow[t]{3}{*}{3} & 100 & 618.14 & 617.24 & 99.85 \\
\hline & & & 615.48 & 99.57 \\
\hline & & & 613.79 & 99.30 \\
\hline \multirow[t]{3}{*}{4} & 150 & 927.21 & 920.48 & 99.27 \\
\hline & & & 914.79 & 98.66 \\
\hline & & & 921.97 & 99.43 \\
\hline
\end{tabular}

Table 13 Results of recovery study for $n$-hexane

\begin{tabular}{|c|c|c|c|c|}
\hline S. no. & Recovery level (\%) & Amount added (ppm) & Amount recovered (ppm) & Recovery (\%) \\
\hline \multirow[t]{3}{*}{1} & LOQ & 30.06 & 29.12 & 96.87 \\
\hline & & & 29.48 & 98.07 \\
\hline & & & 29.75 & 98.97 \\
\hline \multirow[t]{3}{*}{2} & 50 & 150.34 & 149.42 & 99.39 \\
\hline & & & 148.25 & 98.61 \\
\hline & & & 148.79 & 98.97 \\
\hline \multirow[t]{3}{*}{3} & 100 & 300.69 & 299.48 & 99.60 \\
\hline & & & 298.78 & 99.36 \\
\hline & & & 299.98 & 99.76 \\
\hline \multirow[t]{3}{*}{4} & 150 & 451.04 & 449.58 & 99.68 \\
\hline & & & 450.18 & 99.81 \\
\hline & & & 448.87 & 99.52 \\
\hline
\end{tabular}


Table 14 Results of recovery study for ethylacetate

\begin{tabular}{|c|c|c|c|c|}
\hline S. no. & Recovery level (\%) & Amount added (ppm) & Amount recovered (ppm) & Recovery (\%) \\
\hline \multirow[t]{3}{*}{1} & LOQ & 505 & 499.21 & 98.85 \\
\hline & & & 500.24 & 99.06 \\
\hline & & & 499.47 & 98.90 \\
\hline \multirow[t]{3}{*}{2} & 50 & 2525 & 2438.21 & 96.56 \\
\hline & & & 2448.52 & 96.97 \\
\hline & & & 2520.18 & 99.81 \\
\hline \multirow[t]{3}{*}{3} & 100 & 5050 & 4999.18 & 98.99 \\
\hline & & & 5002.41 & 99.06 \\
\hline & & & 5004.89 & 99.11 \\
\hline \multirow[t]{3}{*}{4} & 150 & 7575 & 7499.58 & 99.00 \\
\hline & & & 7568.18 & 99.91 \\
\hline & & & 7512.48 & 99.17 \\
\hline
\end{tabular}

Table 15 Results of recovery study for tetrahydrofuran

\begin{tabular}{|c|c|c|c|c|}
\hline S. no. & Recovery level (\%) & Amount added (ppm) & Amount recovered (ppm) & Recovery (\%) \\
\hline \multirow[t]{3}{*}{1} & LOQ & 73.0536 & 72.17 & 98.79 \\
\hline & & & 72.35 & 99.04 \\
\hline & & & 72.48 & 99.21 \\
\hline \multirow[t]{3}{*}{2} & 50 & 365.268 & 365.16 & 99.97 \\
\hline & & & 364.28 & 99.73 \\
\hline & & & 364.18 & 99.70 \\
\hline \multirow[t]{3}{*}{3} & 100 & 730.536 & 729.48 & 99.86 \\
\hline & & & 731.25 & 100.10 \\
\hline & & & 728.18 & 99.68 \\
\hline \multirow[t]{3}{*}{4} & 150 & 1095.804 & 1091.78 & 99.63 \\
\hline & & & 1094.24 & 99.86 \\
\hline & & & 1091.45 & 99.60 \\
\hline
\end{tabular}

Table 16 Results of recovery study for DIPEA

\begin{tabular}{|c|c|c|c|c|}
\hline S. no. & Recovery level (\%) & Amount added (ppm) & Amount recovered (ppm) & Recovery (\%) \\
\hline \multirow[t]{3}{*}{1} & LOQ & 2.10 & 1.98 & 94.34 \\
\hline & & & 1.94 & 92.44 \\
\hline & & & 1.89 & 90.06 \\
\hline \multirow[t]{3}{*}{2} & 50 & 10.49 & 9.89 & 94.25 \\
\hline & & & 9.78 & 93.20 \\
\hline & & & 9.69 & 92.34 \\
\hline \multirow[t]{3}{*}{3} & 100 & 20.99 & 19.57 & 93.25 \\
\hline & & & 19.78 & 94.25 \\
\hline & & & 18.98 & 90.44 \\
\hline \multirow[t]{3}{*}{4} & 150 & 31.48 & 29.58 & 93.96 \\
\hline & & & 30.14 & 95.74 \\
\hline & & & 29.93 & 95.08 \\
\hline
\end{tabular}


Table 17 Results of precision study for all the solvents

\begin{tabular}{|c|c|c|c|c|c|c|c|c|c|}
\hline \multirow[t]{2}{*}{ Parameter } & \multicolumn{9}{|c|}{ Percentage RSD } \\
\hline & Methanol & Ethanol & Acetone & $\begin{array}{l}\text { Isopropyl } \\
\text { alcohol }\end{array}$ & Dichloromethane & $\begin{array}{l}N- \\
\text { Hexane }\end{array}$ & $\begin{array}{l}\text { Ethyl } \\
\text { acetate }\end{array}$ & Tetrahydrofuran & DIPEA \\
\hline $\begin{array}{l}\text { System precision (standard } \\
\text { solution) (peak area) }\end{array}$ & 2.48 & 3.48 & 1.25 & 0.98 & 0.87 & 0.85 & 1.21 & 0.75 & 0.64 \\
\hline Precision at LOQ (peak area) & 3.51 & 2.78 & 2.49 & 3.48 & 4.51 & 3.98 & 3.48 & 2.85 & 2.18 \\
\hline $\begin{array}{l}\text { Repeatability (intraday) (content } \\
\text { ppm) }\end{array}$ & 0.85 & 0.57 & 0.48 & 0.71 & 0.73 & 0.81 & 0.76 & 0.81 & 0.73 \\
\hline $\begin{array}{l}\text { Intermediate precision (interday) } \\
\text { (content ppm) }\end{array}$ & 0.74 & 0.97 & 0.96 & 0.67 & 0.71 & 0.79 & 0.68 & 0.71 & 0.69 \\
\hline $\begin{array}{l}\text { Cumulative (intraday and } \\
\text { interday) (content ppm) }\end{array}$ & 0.8 & 0.79 & 0.74 & 0.69 & 0.68 & 0.73 & 0.71 & 0.76 & 0.71 \\
\hline
\end{tabular}

Table 18 Limit of detection and limit of quantitation of each solvent

\begin{tabular}{llllll}
\hline S no. & Solvent name & LOQ $(\mathbf{p p m})$ & S/N & LOD (ppm) & S/N \\
\hline 1 & Methanol & 304.695 & 11.2 & 89.616 & 146.466 \\
2 & Ethanol & 497.984 & 10.5 & 146.764 \\
3 & Acetone & 498.996 & 9.8 & 148.381 & 3.5 \\
4 & Isopropyl alcohol & 504.495 & 10.7 & 18.181 & 4.1 \\
5 & Dichloromethane & 61.814 & 11.4 & 8.844 & 3.1 \\
6 & N-hexane & 30.0699 & 11.3 & 148.529 & 2.9 \\
7 & Ethyl acetate & 505 & 9.7 & 21.486 & 3.2 \\
8 & Tetrahydrofuran & 73.0536 & 10.9 & 0.617 \\
\hline
\end{tabular}

Table 19 Robustness study results of methanol

\begin{tabular}{llllll}
\hline Parameter & System conditions & Percentage RSD for peak area $(\boldsymbol{n}=\mathbf{6})$ & Retention time & Plate count & Tailing factor \\
\hline Flow rate $( \pm 0.2 \mathrm{~mL} / \mathrm{min})$ & 2.3 & 2.9 & 5.41 & 59741 & 1.3 \\
& 2.5 & 2.5 & 4.93 & 58451 & 1.0 \\
& 2.7 & 2.2 & 4.44 & 57485 & 1.2 \\
Column oven temperature $\left( \pm 5^{\circ} \mathrm{C}\right)$ & $35^{\circ} \mathrm{C}$ & 3.0 & 5.32 & 59874 & 1.1 \\
& $40^{\circ} \mathrm{C}$ & 2.5 & 4.93 & 58451 & 1.0 \\
& $45^{\circ} \mathrm{C}$ & 2.1 & 4.49 & 58749 & 1.2 \\
Vial oven temperature $\left( \pm 5^{\circ} \mathrm{C}\right)$ & $85^{\circ} \mathrm{C}$ & 2.8 & 4.91 & 54758 & 1.3 \\
& $90^{\circ} \mathrm{C}$ & 2.5 & 4.93 & 58451 & 1.0 \\
& $95^{\circ} \mathrm{C}$ & 2.6 & 4.92 & 58747 & 1.2 \\
\hline
\end{tabular}


Table 20 Robustness study results of ethanol

\begin{tabular}{llllll}
\hline Parameter & System conditions & Percentage RSD for peak area $(\boldsymbol{n}=6)$ & Retention time & Plate count & Tailing factor \\
\hline Flow rate $( \pm 0.2 \mathrm{~mL} / \mathrm{min})$ & 2.3 & 1.7 & 7.32 & 79241 & 1.2 \\
& 2.5 & 1.6 & 6.65 & 78485 & 1.1 \\
& 2.7 & 1.8 & 5.98 & 77142 & 1.2 \\
Column oven temperature $\left( \pm 5^{\circ} \mathrm{C}\right)$ & $35^{\circ} \mathrm{C}$ & 1.4 & 7.29 & 79520 & 1.4 \\
& $40^{\circ} \mathrm{C}$ & 1.6 & 6.65 & 78485 & 1.1 \\
& $45^{\circ} \mathrm{C}$ & 1.5 & 6.10 & 80157 & 1.0 \\
Vial oven temperature $\left( \pm 5^{\circ} \mathrm{C}\right)$ & $85^{\circ} \mathrm{C}$ & 1.5 & 6.64 & 76547 & 1.3 \\
& $90^{\circ} \mathrm{C}$ & 1.6 & 6.65 & 78485 & 1.1 \\
& $95^{\circ} \mathrm{C}$ & 1.7 & 6.63 & 74215 & 1.2 \\
\hline
\end{tabular}

Table 21 Robustness study results of acetone

\begin{tabular}{llllll}
\hline Parameter & System conditions & Percentage RSD for peak area $(\boldsymbol{n}=6)$ & Retention time & Plate count & Tailing factor \\
\hline Flow rate $( \pm 0.2 \mathrm{~mL} / \mathrm{min})$ & 2.3 & 1.3 & 8.53 & 96548 & 1.3 \\
& 2.5 & 1.4 & 7.77 & 95214 & 1.2 \\
& 2.7 & 1.5 & 6.99 & 93245 & 1.4 \\
Column oven temperature $\left( \pm 5^{\circ} \mathrm{C}\right)$ & $35^{\circ} \mathrm{C}$ & 1.2 & 8.61 & 97451 & 1.2 \\
& $40^{\circ} \mathrm{C}$ & 1.4 & 7.77 & 95214 & 1.2 \\
& $45^{\circ} \mathrm{C}$ & 1.3 & 6.98 & 96548 & 1.3 \\
Vial oven temperature $\left( \pm 5^{\circ} \mathrm{C}\right)$ & $85^{\circ} \mathrm{C}$ & 1.3 & 7.69 & 91024 & 1.3 \\
& $90^{\circ} \mathrm{C}$ & 1.4 & 7.77 & 95214 & 1.2 \\
& $95^{\circ} \mathrm{C}$ & 1.4 & 7.72 & 94752 & 1.1 \\
\hline
\end{tabular}

Table 22 Robustness study results of isopropyl alcohol

\begin{tabular}{|c|c|c|c|c|c|}
\hline Parameter & System conditions & Percentage RSD for peak area $(n=6)$ & Retention time & Plate count & Tailing factor \\
\hline \multirow[t]{3}{*}{ Flow rate $( \pm 0.2 \mathrm{~mL} / \mathrm{min})$} & 2.3 & 2.2 & 9.07 & 31248 & 1.2 \\
\hline & 2.5 & 2.0 & 8.25 & 32548 & 1.0 \\
\hline & 2.7 & 2.3 & 7.43 & 32478 & 1.3 \\
\hline \multirow[t]{3}{*}{ Column oven temperature $\left( \pm 5^{\circ} \mathrm{C}\right)$} & $35^{\circ} \mathrm{C}$ & 2.1 & 9.08 & 30214 & 1.2 \\
\hline & $40^{\circ} \mathrm{C}$ & 2.0 & 8.25 & 32548 & 1.0 \\
\hline & $45^{\circ} \mathrm{C}$ & 2.3 & 7.45 & 31067 & 1.4 \\
\hline \multirow[t]{3}{*}{ Vial oven temperature $\left( \pm 5^{\circ} \mathrm{C}\right)$} & $85^{\circ} \mathrm{C}$ & 2.1 & 8.24 & 30148 & 1.3 \\
\hline & $90^{\circ} \mathrm{C}$ & 2.0 & 8.25 & 32548 & 1.0 \\
\hline & $95^{\circ} \mathrm{C}$ & 1.9 & 8.21 & 31032 & 1.1 \\
\hline
\end{tabular}


Table 23 Robustness study results of dichloromethane

\begin{tabular}{llllll}
\hline Parameter & System conditions & Percentage RSD for peak area $(\boldsymbol{n}=6)$ & Retention time & Plate count & Tailing factor \\
\hline Flow rate $( \pm 0.2 \mathrm{~mL} / \mathrm{min})$ & 2.3 & 2.9 & 10.13 & 13982 & 1.3 \\
& 2.5 & 3.2 & 9.21 & 12547 & 1.4 \\
& 2.7 & 2.8 & 8.29 & 11857 & 1.5 \\
Column oven temperature $\left( \pm 5^{\circ} \mathrm{C}\right)$ & $35^{\circ} \mathrm{C}$ & 3.1 & 10.14 & 12478 & 1.2 \\
& $40^{\circ} \mathrm{C}$ & 3.2 & 9.21 & 12547 & 1.4 \\
& $45^{\circ} \mathrm{C}$ & 3.1 & 8.34 & 13415 & 1.3 \\
Vial oven temperature $\left( \pm 5^{\circ} \mathrm{C}\right)$ & $85^{\circ} \mathrm{C}$ & 3.4 & 9.20 & 12145 & 1.1 \\
& $90^{\circ} \mathrm{C}$ & 3.2 & 9.21 & 12547 & 1.4 \\
& $95^{\circ} \mathrm{C}$ & 3.2 & 9.19 & 13245 & 1.2 \\
\hline
\end{tabular}

Table 24 Robustness study results of $\mathrm{N}$-hexane

\begin{tabular}{|c|c|c|c|c|c|}
\hline Parameter & System conditions & Percentage RSD for peak area $(n=6)$ & Retention time & Plate count & Tailing factor \\
\hline \multirow[t]{3}{*}{ Flow rate $( \pm 0.2 \mathrm{~mL} / \mathrm{min})$} & 2.3 & 3.2 & 12.45 & 79584 & 1.0 \\
\hline & 2.5 & 3.4 & 11.31 & 78987 & 1.3 \\
\hline & 2.7 & 3.5 & 10.19 & 72142 & 1.1 \\
\hline \multirow[t]{3}{*}{ Column oven temperature $\left( \pm 5^{\circ} \mathrm{C}\right)$} & $35^{\circ} \mathrm{C}$ & 3.2 & 12.47 & 79658 & 1.1 \\
\hline & $40^{\circ} \mathrm{C}$ & 3.4 & 11.31 & 78987 & 1.3 \\
\hline & $45^{\circ} \mathrm{C}$ & 3.6 & 10.21 & 77415 & 1.2 \\
\hline \multirow[t]{3}{*}{ Vial oven temperature $\left( \pm 5^{\circ} \mathrm{C}\right)$} & $85^{\circ} \mathrm{C}$ & 3.0 & 11.30 & 79584 & 1.3 \\
\hline & $90^{\circ} \mathrm{C}$ & 3.4 & 11.31 & 78987 & 1.3 \\
\hline & $95^{\circ} \mathrm{C}$ & 3.3 & 11.32 & 80154 & 1.2 \\
\hline
\end{tabular}

Table 25 Robustness study results of ethyl acetate

\begin{tabular}{llllll}
\hline Parameter & System conditions & Percentage RSD for peak area $(\boldsymbol{n}=6)$ & Retention time & Plate count & Tailing factor \\
\hline Flow rate $( \pm 0.2 \mathrm{~mL} / \mathrm{min})$ & 2.3 & 1.8 & 15.17 & 66574 & 1.2 \\
& 2.5 & 1.7 & 13.79 & 65848 & 1.1 \\
& 2.7 & 1.9 & 12.41 & 67418 & 1.1 \\
Column oven temperature $\left( \pm 5^{\circ} \mathrm{C}\right)$ & $35^{\circ} \mathrm{C}$ & 1.8 & 15.18 & 64217 & 1.3 \\
& $40^{\circ} \mathrm{C}$ & 1.7 & 13.79 & 65848 & 1.1 \\
& $45^{\circ} \mathrm{C}$ & 1.6 & 12.43 & 66412 & 1.2 \\
Vial oven temperature $\left( \pm 5^{\circ} \mathrm{C}\right)$ & $85^{\circ} \mathrm{C}$ & 1.7 & 13.76 & 64718 & 1.3 \\
& $90^{\circ} \mathrm{C}$ & 1.7 & 13.79 & 65848 & 1.1 \\
& $95^{\circ} \mathrm{C}$ & 1.8 & 13.77 & 63241 & 1.2 \\
\hline
\end{tabular}


Table 26 Robustness study results of tetrahydrofuran

\begin{tabular}{llllll}
\hline Parameter & System conditions & Percentage RSD for peak area $(\boldsymbol{n}=6)$ & Retention time & Plate count & Tailing factor \\
\hline Flow rate $( \pm 0.2 \mathrm{~mL} / \mathrm{min})$ & 2.3 & 2.9 & 15.53 & 97542 & 1.0 \\
& 2.5 & 2.8 & 14.12 & 97845 & 1.0 \\
& 2.7 & 2.7 & 12.71 & 97441 & 1.1 \\
Column oven temperature $\left( \pm 5^{\circ} \mathrm{C}\right)$ & $35^{\circ} \mathrm{C}$ & 2.7 & 15.55 & 97635 & 1.3 \\
& $40^{\circ} \mathrm{C}$ & 2.8 & 14.12 & 97845 & 1.0 \\
& $45^{\circ} \mathrm{C}$ & 2.7 & 12.74 & 97412 & 1.2 \\
Vial oven temperature $\left( \pm 5^{\circ} \mathrm{C}\right)$ & $85^{\circ} \mathrm{C}$ & 2.7 & 14.11 & 97458 & 1.4 \\
& $90^{\circ} \mathrm{C}$ & 2.8 & 14.12 & 97845 & 1.0 \\
& $95^{\circ} \mathrm{C}$ & 2.7 & 14.12 & 96547 & 1.3 \\
\hline
\end{tabular}

intercept $<5.0 \%$ showing a good correlation between the response and solvent concentration (Tables 5, 6 and 7). The linearity of the method was confirmed statistically. The calculated limit of detection and limit of quantitation for each solvent found to be satisfactory (Table 18). The method is robust as in robustness parameter with deliberate changes made for which individual and cumulative RSD values for each set were $<5.0 \%$ (Tables 19, 20, 21, 22, 23, 24, 25, 26, and 27). All the obtained results from the validation parameters were found to be meeting to the $\mathrm{ICH}$ acceptance criteria [30]. Finally, the anticipated method was found to be suitable for the routine analysis in the research laboratories as well as in the quality control.

\section{Conclusion}

The developed gas chromatographic method with FID detector offers simplicity, selectivity, precision, accuracy, and robust. It produces symmetric peak shape and reasonable retention time for all the solvents. It often can

Table 27 Robustness study results of DIPEA

\begin{tabular}{llllll}
\hline Parameter & $\begin{array}{l}\text { System } \\
\text { conditions }\end{array}$ & $\begin{array}{l}\text { Percentage } \\
\text { RSD for } \\
\text { peak area } \\
(\boldsymbol{n}=\mathbf{6})\end{array}$ & $\begin{array}{l}\text { Retention } \\
\text { time }\end{array}$ & $\begin{array}{l}\text { Plate } \\
\text { count }\end{array}$ & $\begin{array}{l}\text { Tailing } \\
\text { factor }\end{array}$ \\
\hline $\begin{array}{lllll}\text { Flow rate } \\
( \pm 0.2 \mathrm{~mL} / \mathrm{min})\end{array}$ & 2.3 & 3.9 & 19.20 & 93487 & 1.1 \\
& 2.5 & 3.5 & 17.45 & 98751 & 1.2 \\
& 2.7 & 3.4 & 15.72 & 95249 & 1.1 \\
Column oven & $35^{\circ} \mathrm{C}$ & 3.1 & 19.23 & 97541 & 1.2 \\
temperature & $40^{\circ} \mathrm{C}$ & 3.5 & 17.45 & 98751 & 1.2 \\
$\left( \pm 5^{\circ} \mathrm{C}\right)$ & $45^{\circ} \mathrm{C}$ & 3.2 & 15.74 & 96324 & 1.2 \\
& $85^{\circ} \mathrm{C}$ & 3.4 & 17.46 & 97547 & 1.3 \\
Vial oven & $90^{\circ} \mathrm{C}$ & 3.5 & 17.45 & 98751 & 1.2 \\
temperature & $95^{\circ} \mathrm{C}$ & 3.5 & 17.42 & 97452 & 1.2 \\
\hline \begin{tabular}{l} 
$\left.\pm 5^{\circ} \mathrm{C}\right)$ \\
\hline
\end{tabular} & & & & & \\
\hline
\end{tabular}

be seen from the chromatogram that all the solvents were eluted before 25 min of injection of sample. It can be used for the determination of residual solvents in PACLITAXEL API, and this method can even be used to separate the residual solvents present in other drug substances and also within the finished dosage forms where the particular solvents used for the coating purpose or any other excipients within the pharmaceutical companies and research laboratories and also be advantageous for scale manufacturing purpose.

\section{Abbreviations}

API: Active pharmaceutical ingredient; DIPEA: N,N-di-isopropyl ethyl amine; FID: Flame ionization detector; ICH: International Conference on Harmonisation; NA: Not applicable; NLT: Not less than; NMT: Not more than; NMP: N-methyl-2-pyrrolidinone; RSD: Relative standard deviation; S/N: Signalto-noise ratio

\section{Acknowledgements}

We are thankful for all those who have supported us during this research work.

\section{Authors' contributions}

NK conducted the literature study, designed, developed and validated the gas chromatographic method. NK and AR compiled, analyzed and interpreted the data. NK wrote the manuscript. All authors read and approved the final manuscript.

\section{Funding}

There is no funding source for this project.

\section{Availability of data and materials}

The datasets used and/or analysed during the current study are available from the corresponding author on reasonable request.

Ethics approval and consent to participate

Not applicable.

Consent for publication

Not applicable.

\section{Competing interests}

The authors declare that they have no competing interests.

\section{Author details}

'Department of Pharmaceutical Sciences, Acharya Nagarjuna University, Nagarjunanagar, Guntur, Andhra Pradesh 522510, India. ${ }^{2}$ Department of 
Pharmacy, Nirmala College of Pharmacy, Atmakur, Mangalagiri, Guntur, Andhra Pradesh 522503, India.

Received: 3 August 2020 Accepted: 14 January 2021

Published online: 10 February 2021

\section{References}

1. O'Neil MJ, Smith A, Heckelman PE (2006) The Merck Index, An Encyclopedia of Chemicals, Drugs and Biologicals, 14th edn. Merck \& Co. Inc., White House Station, p 1204

2. Sweetman SC (2006) Martindale the Complete Drug Reference, 35th edn. Pharmaceutical Press, London, p 685

3. Zentner GM, Rathi R, Shih C, McRea JC, Seo M, Rhee BG, Mestecky J, Moldoveanu Z, Morgan M, Weitman S (2001) Biodegradable block copolymers for delivery of proteins and water-insoluble drugs. J Control Release 72:203-215

4. Arbuck SG, Blaylock B (1995) TAXOL: clinical results and current issues in development. In TAXOL: Science and Applications. M. Suffness, ed. CRC Press, New York, p 379

5. U.S. Food and Drug Administration (2003) Q3A Impurities in New Drug Substances. Food and Drug Administration, Washington, DC

6. U.S. Food and Drug Administration (2006) Q3B Impurities in New Drug Products. Food and Drug Administration, United States

7. Gorog S (2000) Identification and Determination of Impurities in Drugs. Elsevier Science, B.V, Amsterdam

8. Bhowmik H, Venkatesh DN (2001) Nanosponges: A review. Int J Appl Pharms 10:1-5

9. Hovorka S, Schöneich C (2001) Oxidative degradation of pharmaceuticals: Theory, mechanisms and inhibition. J Pharm Sci. 90:253-269

10. Roy J (2002) Pharmaceutical impurities - a mini-review. AAPS Pharm Sci Tech 3:E6

11. ICH Harmonised Tripartite Guidelines: Q3A(R2). Impurities in New Drug Substances International Conference on Harmonisation; 2006

12. ICH Harmonised Tripartite Guidelines: Q3B(R6). Impurities in New Drug Products International Conference on Harmonisation; 2006

13. ICH Harmonised Tripartite Guidelines: Q3C(R2). Maintenance of the guidelines for Residual Solvents; International Conference on Harmonisation; 2016

14. ICH Harmonised Tripartite Guidelines: Q1A(R2). Stability Testing of New Drug Substances and Products; International Conference on Harmonisation; 2003

15. Haky JE, Stickney TM (1985) Automated gas chromatographic method for the determination of residual solvents in bulk pharmaceuticals. J Chrom. 321:137-144

16. Markovich RJ, Ong S, Rosen J (1997) J Chrom Sci 35:584-592

17. Zhu JY, Chai XS (2005) Some recent developments in headspace gas chromatography. Curr Anal Chem. 1:79-83

18. Hempel G, Lehmkuhl D, Krumpelmann S, Blaschkle G, Boos J (1996) Determination of paclitaxel in biological fluids by micellar electrokinetic chromatography. J Chrom A. 745:173

19. Theodoridis G, Laskaris G, Rozendaal ELM, Verpoorte R (2001) Analysis of taxines in Taxus plant material and cell cultures by HPLC photodiode array and HPLC-electrospray mass spectrometry. J Liquid Chrom. 24:2267

20. Nguyen T, Eshraghi J, Gonyea R, Ream R, Smith R (2001) Studies on factors influencing stability and recovery of paclitaxel from suspension media and cultures of Taxus cuspidata Densiformis by high-performance liquid chromatography. J Chroma A.911:55

21. Aboul-Enein HY, Serignese V (1996) Liquid chromatographic determination of taxol and related derivatives using a new polyfluorinated reversedpphase column. Analytica Chimica Acta. 319:187

22. Fu Y, Sun R, Zu Y (2009) Simultaneous determination of main taxoids in Taxus needles extracts by solid-phase extraction-high-performance liquid chromatography with pentafluorophenyl column. Biomed Chrom. 23:63-70

23. Shao L'Locke D (1997) Determination of paclitaxel and related taxanes in bulk drug and injectable dosage forms by reversed phase liquid chromatography. Anal Chem. 69:2008-2016

24. Badea I, Ciutaru D, Lazar L (2004) Rapid HPLC method for the determination of paclitaxel in pharmaceutical forms without separation. J Pharm Biomed Anal. 34:501-507
25. Ciutaru D, Badea I, Lazara L (2004) A HPLC validated assay of paclitaxel's related impurities in pharmaceutical forms containing Cremophor EL. J Pharm Biomed Anal. 34:493-499

26. United States Pharmacopoeia (2004) United States Pharmacopoeia Convention, pp 1394-1396

27. Sun $P$, Wang $X$, Alquier $L$ (2008) Determination of relative response factors of impurities in paclitaxel with high performance liquid chromatography equipped with ultraviolet and charged aerosol detectors. J Chrom A. 1177: 87-91

28. Beijing China (2010) Chinese Pharmacopoeia Commission. Beijing, Chinese Pharmacopoeia (Parta), pp 1007-1008

29. Volka K, Hill S, Kerns E (1997) Profiling degradants of paclitaxel using liquid chromatography-mass spectrometry and liquid chromatography-tandem mass spectrometry substructural techniques. J Chrom B Biomed Sci Appl. 696:99-115

30. Harmonised Tripartite Guideline ICH (2005) Validation of Analytical Procedures: Text and Methodology Q2(R1)

\section{Publisher's Note}

Springer Nature remains neutral with regard to jurisdictional claims in published maps and institutional affiliations.

\section{Submit your manuscript to a SpringerOpen ${ }^{\circ}$ journal and benefit from:}

- Convenient online submission

- Rigorous peer review

- Open access: articles freely available online

- High visibility within the field

- Retaining the copyright to your article

Submit your next manuscript at $\boldsymbol{\nabla}$ springeropen.com 